\title{
Prevention of Glucoprivic Stimulation of Corticosterone Secretion by Leptin Does Not Restore High Frequency Luteinizing Hormone Pulses in Rats
}

\author{
S. Nagatani,* R. C. Thompson* and D. L. Foster*† \\ *Reproductive Sciences Program, †ंDepartments of Obstetrics and Gynecology and Biology, University of Michigan, Ann Arbor, MI, USA.
}

Key words: leptin, LH, glucose availability, immobilization, corticosterone.

\begin{abstract}
We have previously determined that exogenous leptin prevents the inhibition of pulsatile luteinizing hormone (LH) release in the fasting rodent. The present study tested the hypothesis that the mechanism by which leptin facilitates high LH secretion is through an attenuation of the stress response produced by a deficit in energy. Because hypogonadotropism is associated with activation of the hypothalamic-pituitary-adrenal (HPA) axis during both metabolic stress and nonmetabolic stress, our approach included a comparison of whether exogenous leptin could prevent the rise in corticosterone produced by a nonmetabolic stress (immobilization for $2 \mathrm{~h}$ ), as well as by a widely used metabolic stress (transient glucoprivation by 2-deoxyglucose, 2DG; $400 \mathrm{mg} / \mathrm{kg}$, b.w., i.v.). Each stressor was applied to well-fed ovariectomized rats ( $n=4-6$ per group), $2 \mathrm{~h}$ after leptin ( $3 \mu \mathrm{g} / \mathrm{g}$, b.w., i.p.) or vehicle administration. Blood samples were collected through an indwelling atrial cannula every $6 \mathrm{~min}$ for $1 \mathrm{~h}$ before and for $2 \mathrm{~h}$ after the stress treatment to measure $\mathrm{LH}$, leptin and corticosterone. During metabolic stress (acute glucoprivation), circulating leptin decreased, corticosterone increased and LH decreased; leptin administration abolished the increase in corticosterone, but pulsatile LH secretion remained inhibited. In contrast, during nonmetabolic stress (immobilization), leptin secretion was unaffected, but circulating corticosterone increased and LH decreased; leptin treatment did not prevent either the increase in corticosterone or the decrease in LH secretion. An important overall finding is that leptin can differentially alter the HPA axis depending upon the type of stress. In addition, whether the pattern of leptin is altered depends upon the type of stress. Although a glucoprivic-induced decrease in endogenous leptin can be a stressor responsible for the increase in corticosterone secretion, a nonmetabolic stress-induced increase in corticosterone is not mediated by leptin. Moreover, our results reveal that the depression of LH secretion when leptin is low during reduced energy availability is not due to activation of the HPA axis. During an energy deficit, exogenous leptin could not restore high frequency LH secretion when HPA function was restored to normal. Finally, the inability of leptin to increase LH secretion in the face of 2DG supports the notion that the action of leptin is dependent upon the degree of glucose availability.
\end{abstract}

A reduction in food intake suppresses reproductive function by reducing gonadotropin secretion in many mammalian species (1-4). Extensive efforts have focused on the identification of nutritional signals that convey information about somatic nutritional state into the central nervous system to regulate hypothalamic gonadotropin releasing hormone (GnRH) secretion. The discovery of leptin (5) raised the possibility that this secretory product of adipose tissue could be one of these signals $(6,7)$. In our recent study of the fasted hypoleptinemic rat, leptin replacement prevented inhibition of pulsatile luteinizing hormone (LH) secretion (8). A similar effect of leptin has been found in the fasting monkey (9) and sheep (10).

The physiological mechanism whereby leptin regulates the LH release remains unclear, but it could involve the hypothalamic-pituitary-adrenal (HPA) axis. The increase in circulating adrenocorticotropic hormone (ACTH) and corticosterone concentrations in the fasting mouse (11) and in

Correspondence to: Douglas L. Foster, Room 1101, 300 North Ingalls Building, University of Michigan, Ann Arbor, Michigan 48109-0404, USA (e-mail: dlfoster@umich.edu). 
leptin-deficit $o b / o b$ mouse (12) raises the possibility that an increase in hypothalamic corticotropin releasing hormone $(\mathrm{CRH})$ activity may play a role. This peptide has been proposed to mediate the suppression of the LH secretion by nutritional challenge, because an i.c.v. injection of a CRH antagonist abolishes the fasting-induced LH suppression (13). It is also possible that leptin counteracts the increase in the HPA axis activity during fasting to restore gonadotropin secretion. Leptin treatment of the $o b / o b$ mouse, as well as of the fasting wild-type mouse, ameliorates both hypercortisolemia $(11,12)$ and infertility $(11,14-16)$. Nevertheless, it is unclear how leptin regulates the activity of the HPA axis. One likely possibility may be the leptin's regulation of energy availability, because leptin is known to enhance energy utilization in tissues $(17,18)$. In this respect, the decline in glucose availability could serve to activate the HPA axis, as evidenced by the increase in circulating ACTH and corticosterone (19), and the depression in LH secretion (20) during transient glucoprivation produced with a competitive antagonist of glucose (2-deoxyglucose, 2DG). However, we cannot exclude the alternative possibility of a direct interplay between leptin and the HPA axis. Although LH secretion is not determined, Heiman et al. (21) have shown that leptin administration attenuates restraint stress-induced increases in plasma ACTH and corticosterone levels in mice.

The purpose of the present study was to evaluate the hypothesis that the mechanism by which leptin facilitates high LH secretion is through an attenuation of the stress response produced by a deficit in energy. To control for the possibility that leptin interacts with the HPA axis per se in its regulation of LH secretion, we assessed two different stress responses. We compared whether exogenous leptin could prevent the rise in corticosterone, as an indicator of HPA-axis activity, produced by a nonmetabolic stress (immobilization) and the rise in corticosterone produced by a widely used metabolic stress (transient glucoprivation by $2 \mathrm{DG}$ ).

\section{Materials and methods}

Animals

Adult female Sprague-Dawley strain rats (weighing 260-290 g; Charles River, Wilmington, MA, USA) were individually housed under a controlled environment ( $12 \mathrm{~h}$ of light, $12 \mathrm{~h}$ of darkness; lights on at $07.00 \mathrm{~h}$; temperature at $22 \pm 1^{\circ} \mathrm{C}$ ), and were provided with regular Purina chow and water ad libitum in the Reproductive Sciences Program Small Animal Core Facility. All animals were bilaterally ovariectomized (OVX) under an anaesthesia of a single ip injection of xylazine (15 mg/kg, Bayer Corporation, Shawnee, KS, USA) and ketamine $(100 \mathrm{mg} / \mathrm{kg}$, Fort Dodge Laboratories Inc., Fort Dodge, IA, USA). All procedures were approved by the University Committee on Use and Care of Animals at the University of Michigan.

\section{Experimental protocol}

The study was conducted in the absence of ovarian steroids to simplify the experimental model by eliminating any changing effects of sex steroid negative feedback on LH secretion. Two weeks after ovariectomy, animals were randomly assigned into five experimental groups (4-6 animals per group): (i) vehicle-treated + metabolic stress (glucoprivation, 2DG); (ii) leptintreated + metabolic stress; (iii) vehicle-treated + nonmetabolic stress (immobilization); (4) leptin-treated + nonmetabolic stress; and (v) vehicle-treated. To induce transient glucoprivation, 2DG (Sigma Chemical, St Louis, MO, USA) dissolved in $400 \mu \mathrm{l}$ of saline were injected intravenously at a dose of $400 \mathrm{mg} / \mathrm{kg}$. We previously reported $(20,22)$ that this treatment inhibits LH secretion in ovariectomized rats without affecting locomotive behaviour. Immobilization was performed by laying rats on their stomach and taping all limbs to a piece of plastic board for the duration of blood sampling $(2 \mathrm{~h})$. This procedure had been confirmed to suppress LH secretion in pilot studies. Groups 2 and 4 received recombinant murine leptin ( $3 \mu \mathrm{g} / \mathrm{g}$, b.w., i.p.), generously provided by Amgen Inc. (Thousand Oaks, CA, USA), and the rest of groups received vehicle (phosphate-buffered saline, PBS). We have previously demonstrated that this leptin preparation prevents fasting-induced decrease in pulsatile $\mathrm{LH}$ secretion in the rat (8). A fifth group that was treated with PBS and remained unstressed was used as a control to assess possible diurnal changes in leptin $(11,23-25)$ and corticosterone $(11,25)$ secretion throughout the sampling period. Animals in this group served for control of immobilization because they were not restrained, but they were handled. They also served as an osmotic control for $2 \mathrm{DG}$ as they were treated with the same dose $(400 \mathrm{mg} / \mathrm{kg})$ of a nonmetabolizable sugar, xylose (Sigma) that was used for 2DG. Xylose in our previous studies was without effect on $\mathrm{LH}$ secretion $(20,22,26)$.

Leptin was administered as a single injection at hour -2 to one group of rats. Blood collection began $1 \mathrm{~h}$ after the leptin treatment (hour -1 ). To evaluate the effect of leptin on the pattern of pulsatile $\mathrm{LH}$ secretion for the first $1 \mathrm{~h}$ of blood collection, the stressors were not applied until $2 \mathrm{~h}$ after leptin pretreatment (hour 0). The dose of leptin and time course of leptin pretreatment for the nonmetabolic stress treatment were chosen based on a previous report in which leptin, administered (i.p., 2 or $4 \mu \mathrm{g} / \mathrm{g}$ ) $2 \mathrm{~h}$ before beginning of stress (2-h restraint), reduces the stress response (rise in corticosterone) in mice (21).

\section{Blood collection}

Blood samples (approximately $100 \mu \mathrm{l}$ ) were collected every $6 \mathrm{~min}$ interval for $3 \mathrm{~h}$ through an indwelling atrial cannula (Silastic tubing, $0.64 \mathrm{~mm}$ i.d. $\times$ 1.19 mm o.d.; Dow Corning, Midland, MI, USA) which had been inserted the previous day under the ketamine/xylazine anaesthesia. An equivalent volume of sterile heparinized saline $(10 \mathrm{U} / \mathrm{ml})$ was replaced at each sample removal. Blood plasma was separated by centrifugation, $30 \mu \mathrm{l}$ of plasma were aliquoted for $\mathrm{LH}$, and the remaining plasma (approximately $30 \mu \mathrm{l}$ per tube) for each animal was pooled for each five samples (30-min time bins) for quantification of leptin, and corticosterone. Plasma samples were stored at $-20^{\circ} \mathrm{C}$ until assayed.

\section{Hormone assays}

Plasma LH concentrations were determined in single aliquot by a double antibody radioimmunoassay (RIA) with rat LH RIA reagents provided by the National Hormone and Pituitary Program (Baltimore, MD, USA) and are expressed in terms of NIADDK-rLH-RP-3. Assay sensitivity, defined as 2 SD from the buffer control, averaged $0.027 \mathrm{ng} / \mathrm{ml}$ at $95.4 \%$ of $\mathrm{B} / \mathrm{Bo}(\mathrm{n}=3$ assays) for $30 \mu \mathrm{l}$ plasma, and the intra- and interassay coefficients of variation were $5.60 \%$ and $11.80 \%$ at $75.8 \%$ of $\mathrm{B} / \mathrm{Bo}$, respectively. Leptin was measured in single $100 \mu \mathrm{l}$ aliquot of the pooled plasma using a Rat Leptin RIA Kit (Linco Research Inc., St Charles, MO, USA; $100 \%$ cross-reactivity with mouse leptin). Assay sensitivity, defined as $2 \mathrm{SD}$ from the buffer control, averaged $0.12 \mathrm{ng} / \mathrm{ml}$ at $96 \%$ of $\mathrm{B} / \mathrm{Bo}(\mathrm{n}=2$ assays) for $100 \mu \mathrm{l}$ plasma. The intra- and interassay coefficients of variation were $3.37 \%$ and $12.84 \%$ at $71 \%$ of $\mathrm{B} / \mathrm{Bo}$, respectively. Corticosterone was measured in single $50 \mu \mathrm{l}$ aliquot of the pooled plasma using a corticosterone ${ }^{125}$ I RIA Kit (Diagnostic Products kit, Diagnostic Systems Laboratories, Inc. Webster, TX, USA). Assay sensitivity, defined as $2 \mathrm{SD}$ from the buffer control, averaged $0.004 \mu \mathrm{g} / \mathrm{ml}$ at $97.3 \%$ of $\mathrm{B} / \mathrm{Bo}(\mathrm{n}=1$ assay) for $50 \mu \mathrm{l}$ plasma, and the intra-assay coefficient of variation was $3.20 \%$ at $87.6 \%$ of $\mathrm{B} / \mathrm{Bo}$.

\section{Statistical analysis}

LH pulses were identified by the Cluster Analysis, developed by Veldhuis and Johnson (27) using a modification of the parameters previously described (28). Mean LH concentrations and the frequency and amplitude of LH pulses were calculated in each individual and then for groups. To evaluate the effect of stress on the parameters of LH secretion, plasma leptin and corticosterone concentrations, percent changes in hormone levels after stress were determined. In each individual, the average control level from the values of the first $1 \mathrm{~h}$ was determined for each hormone, and the percent changes from the mean in concentrations at each time point after stress treatment were calculated. Statistical differences among groups were determined by analysis of variance. Post-hoc comparisons were made by Duncan's multiple range test. Student's t-test was used to compare mean leptin and corticosterone levels between the first hour and the second or the third hour in the nonstressed 
Leptin, stress and reproduction 373

control group, and to determine the effect of leptin on mean corticosterone levels and LH pulse parameters before stress (hour -1 to 0 ).

\section{Results}

\section{Leptin and corticosterone}

The patterns of circulating corticosterone and leptin throughout 3 -h sampling period in representative individuals are shown in Fig. 1. In the nonstressed control group, there were no significant differences in plasma leptin or corticosterone levels between the first hour $(1.28 \pm 0.14 \mathrm{ng} / \mathrm{ml}$ in leptin; $0.33 \pm 0.03 \mu \mathrm{g} / \mathrm{ml}$ in corticosterone) and the second $(1.27 \pm 0.19 \mathrm{ng} / \mathrm{ml} ; 0.36 \pm 0.05 \mu \mathrm{g} / \mathrm{ml})$ or the third hour $(1.21 \pm 0.25 \mathrm{ng} / \mathrm{ml} ; 0.36 \pm 0.05 \mu \mathrm{g} / \mathrm{ml})$. Thus, there were no fluctuations in patterns of leptin or corticosterone to confound the effects of short-term stress treatments. Before the application of either type of stress, the level of corticosterone

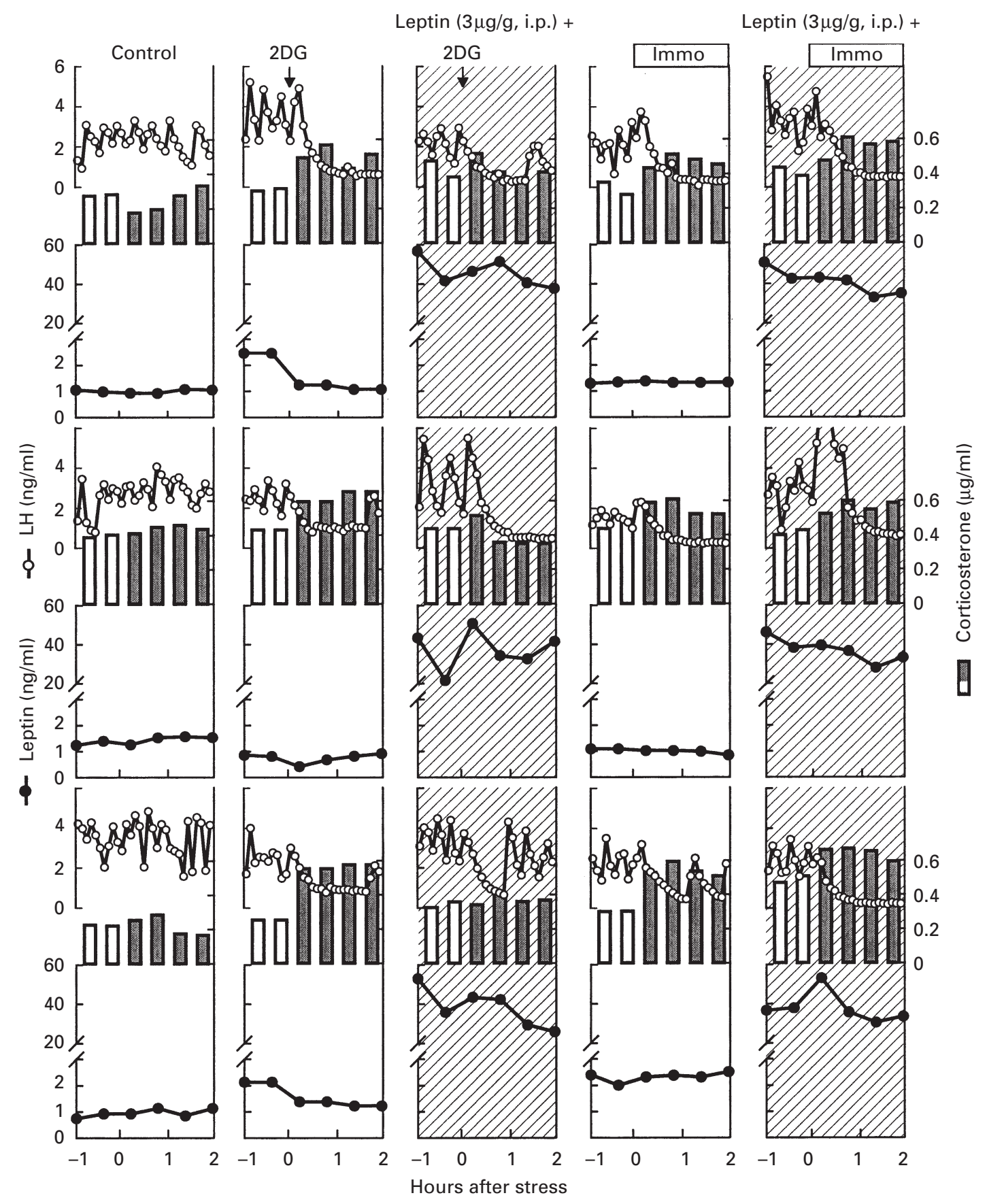

FIG. 1. Representative profiles of pulsatile luteinizing hormone (LH) secretion, plasma corticosterone and leptin concentrations before and after 2-deoxyglucose (2DG) $(400 \mathrm{mg} / \mathrm{kg}$, i.v.) treatment or immobilization (immo) in ovariectomized rats with or without leptin pretreatment (3 $\mu \mathrm{g} / \mathrm{g}$, i.p.). Each panel contains data from a different rat. 
374 Leptin, stress and reproduction

TAble 1. Effect of Exogenous Leptin ( $3 \mu \mathrm{g} / \mathrm{g}$, b.w.) on Plasma Corticosterone Concentrations and Luteinizing Hormone (LH) Pulse Parameters (means \pm SEM) Before Stress (Hours -1 to 0 ).

Corticosterone

LH

\begin{tabular}{|c|c|c|c|c|c|c|c|}
\hline \multicolumn{2}{|l|}{ Mean $(\mu \mathrm{g} / \mathrm{ml})$} & \multicolumn{2}{|c|}{ Mean (ng/ml) } & \multicolumn{2}{|c|}{ Pulse frequency (pulses/1 h) } & \multicolumn{2}{|c|}{ Pulse amplitude (ng/ml) } \\
\hline $\operatorname{PBS}(\mathrm{n}=17)$ & Leptin $(n=10)$ & PBS & Leptin & PBS & Leptin & PBS & Leptin \\
\hline $0.37 \pm 0.02$ & $0.41 \pm 0.02^{*}$ & $2.73 \pm 0.18$ & $2.60 \pm 0.21 *$ & $2.82 \pm 0.13$ & $2.78 \pm 0.2^{*}$ & $1.56 \pm 0.12$ & $1.74 \pm 0.19^{*}$ \\
\hline
\end{tabular}

*NS, nonsignificant difference versus phosphate buffered saline (PBS) control group (Student's t-test).

Table 2. Percent Changes in Mean Luteinizing Hormone (LH), LH Pulse Frequency and the Amplitude After 2-Deoxyglucose (2DG) Treatment or Immobilization (immo) With or Without Exogenous Leptin.

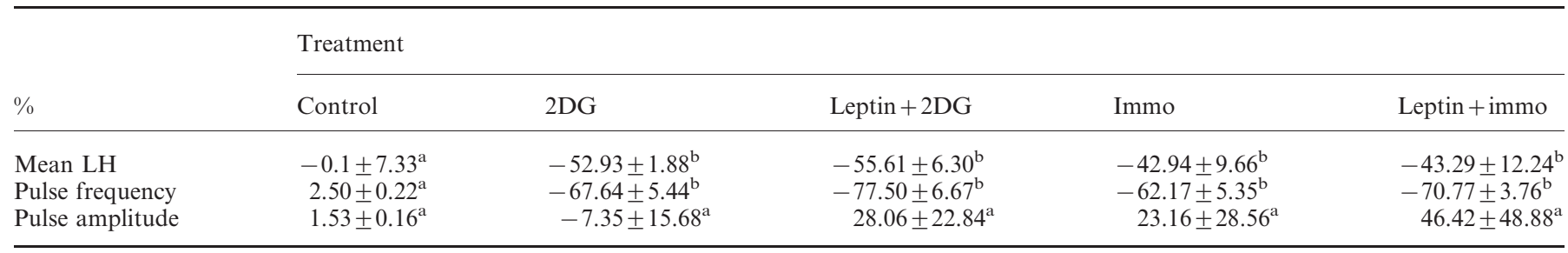

Values are mean \pm SEM. Different superscript letters indicate a significant difference among groups $(\mathrm{P}<0.05)$ by Duncan's multiple range test.

secretion was not altered (Table 1) by the leptin treatment. Our control plasma corticosterone levels in females are within variation of the reference data (Diagnostic Products). Basal corticosterone levels differ between genders in the rat, and females show much higher plasma concentrations of the hormone than the counterpart (29) (see data published in the instruction the Diagnostic Products assay kit). Exogenous leptin resulted in an 18.7-fold (mean during hour -1 to 0 ) higher circulating leptin concentrations over normal levels.

In the metabolic-stressor experiment, administration of 2DG significantly decreased plasma leptin and increased plasma corticosterone above basal levels from $1-2 \mathrm{~h}$ after the injection (Fig. 2). Leptin-pretreatment prevented this 2DG-induced increase in plasma corticosterone (Fig. 2). In the nonmetabolic-stressor experiment, immobilization also increased plasma corticosterone above the basal levels, but exogenous leptin could not prevent this increase in corticosterone (Fig. 2).

\section{$L H$}

Exogenous leptin did not change the pattern (Fig. 1) or level (Table 1) of LH secretion before the application of either type of stress (hours -1 to 0 ). In the absence of leptin when circulating corticosterone was increased, either 2DG or immobilization abruptly blocked pulsatility of LH secretion (Fig. 1) and reduced all parameters of $\mathrm{LH}$ secretion $(\mathrm{P}<0.05$, Table 2). Leptin treatment did not reverse the suppression of LH secretion induced by either stressor regardless of whether corticosterone was suppressed (glucoprivation) or remained increased (immobilization) (Fig. 1 and Table 2).

\section{Discussion}

The present results argue against the simple hypothesis that leptin counteracts the stress response (activation of the HPA axis) to reinstate $\mathrm{LH}$ secretion. We found that leptin can prevent the increase in plasma corticosterone concentrations induced by a metabolic stress (glucoprivation), but yet the amplitude and frequency of LH pulses are not restored to normal by leptin. Such findings bear upon several issues, namely the relationships between leptin and activity of the HPA axis, between activation of the HPA axis and LH secretion, and among leptin, glucose availability and LH secretion.

\section{Leptin and activity of the HPA axis}

The present study revealed interesting associations between the ability of leptin to ameliorate different types of stress and the ability of different types of stress to regulate its secretion. We found that leptin was unable to prevent the increase in plasma corticosterone induced by a nonmetabolic stress. This finding contrasts with that of Heiman et al. (21), who reported that leptin attenuated the increase of plasma ACTH and corticosterone in restrained mice. Regardless of the discrepancy, this same treatment was able to prevent the rise in corticosterone induced by a metabolic stress (glucoprivation). This suggests that the action of leptin depends on the type of stress. The regulation of leptin secretion also depends on the type of stress. Glucoprivation, but not immobilization, inhibited endogenous leptin secretion when plasma corticosterone started to increase. Among the many substances involved in the regulation of leptin secretion, insulin is known to be a potent stimulator. The fasting-induced decrease 


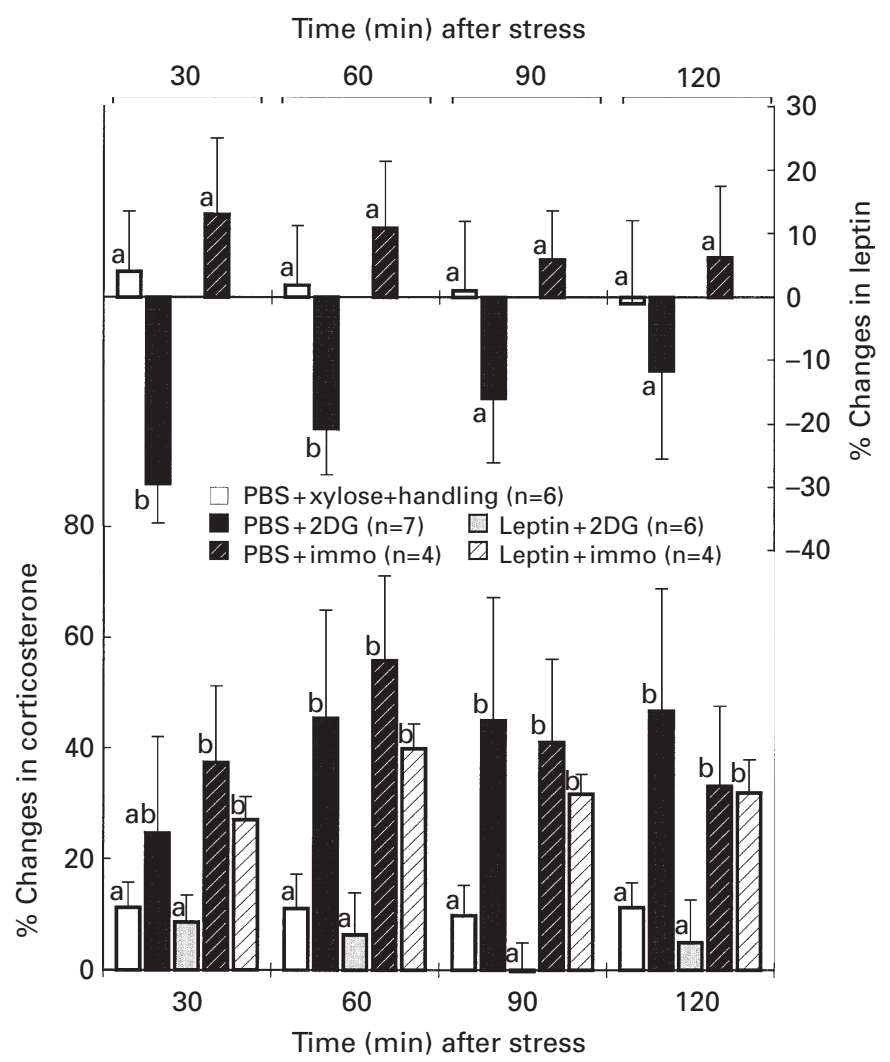

FIG. 2. Percent changes in plasma leptin and corticosterone levels after 2deoxyglucose (2DG) treatment or immobilization (immo) with or without exogenous leptin. Values are mean \pm SEM. Different letters indicate significant difference among groups $(\mathrm{P}<0.05)$ at each time after stress by Duncan's multiple range test.

in plasma leptin is reversed by insulin replacement (30). Recently, Mueller et al. (31) have found that glucose metabolism mediates the increase in leptin secretion by insulin in vitro. In their study, insulin-induced leptin secretion from isolated rat adipocytes is inhibited by the addition of $2 \mathrm{DG}$ to the incubation medium. In accordance with their finding, the present in vivo results show that a reduction in glucose availability by 2DG inhibits leptin secretion. Furthermore, our experiment suggests that the reduction of leptin secretion is responsible for the glucoprivic increase in the corticosterone concentrations, because exogenous leptin abolished the changes in corticosterone. However, this conclusion needs tempered, because glucoprivation per se stimulates CRH release regardless of the presence of leptin in in vitro studies. Previous reports have shown that $\mathrm{CRH}$ release is stimulated from hypothalamic explants during glucoprivation by the addition of 2DG into leptin-free medium (32) or by the withdrawal of glucose from the leptin-free medium (21). In the latter study, the addition of leptin abolished the increase in CRH (21). Taken these results together, it is plausible that leptin serves as a permissive factor such that low concentrations allow glucoprivation to stimulate $\mathrm{CRH}$ neurones.

\section{Activation of the HPA axis and LH secretion}

Our study provides evidence for differential roles of leptin on the stress and reproductive axes. It is well recognized that stress inhibits reproductive function (33). Most studies that have examined the role of the HPA axis on the stressinduced suppression of LH secretion have concluded that the hypothalamic component of the axis is involved in the suppression. In this respect, an intracranial injection of $\mathrm{CRH}$ was found to depress plasma LH concentrations in the rat (34-36) and monkey (37-39), and a CRH antagonist blocked the decline of the LH levels induced by foot-shock stress in the rat (40). In the present study, leptin prevented an increase in plasma corticosterone concentrations induced by a glucoprivic stress without affecting the stress-induced suppression of pulsatile LH secretion. Some evidence exists in vitro that leptin can inhibit corticosterone secretion by acting at the level of the adrenal gland, but not at the anterior pituitary (41). Based on this in vitro evidence, we would have expected that in our in vivo study leptin to block all stress responses regardless of how they are induced. However, we found that while leptin could suppress the glucoprivic-induced increase in corticosterone levels, it did not prevent those induced by immobilization (discussed above). Thus, it is possible that the action of leptin is mediated through $\mathrm{CRH}$ neurones rather than at the level of the pituitary gland or adrenal gland. Leptin receptor has been found in the CRH neurones in the parvocellular part of the hypothalamic paraventricular nucleus (42), a site where some CRH neurones project to the median eminence $(43,44)$. Because leptin replacement did not reverse $2 \mathrm{DG}$-induced inhibition of LH secretion, the mechanism by which leptin regulates the stress axis appears to be independent from the mechanism whereby leptin influences the reproductive axis. If $\mathrm{CRH}$ regulation is involved in leptin action, then why does leptin not restore normal LH secretion when it prevents activation of the HPA axis (corticosterone increase) by glucoprivation? Most likely, a second pathway plays a role in inhibiting LH secretion during stress, a pathway that does not involve the pituitary or adrenal glands. In this regard, $\mathrm{CRH}$ axon terminals have been found to contact synaptically with $\mathrm{GnRH}$ dendrites in the rat medial preoptic area (45), where local infusion of $\mathrm{CRH}$ inhibits GnRH secretion in the median eminence (46).

\section{Glucose availability and LH secretion}

Finally, the important question may be raised as to why preventing the decline of circulating leptin abolishes the suppression of LH during fasting, but not during glucoprivation. We used the same dose and route of administration as in our previous study which the fasting-induced suppression of LH secretion was restored to normal (8). Although the duration of exposure was less in the present study ( $3 \mathrm{~h}$ versus $40 \mathrm{~h}$ ), exogenous leptin was clearly able to exert a biological action within the 3 -h time frame as evidenced by its ability to prevent the glucoprivic rise in corticosterone. Another explanation for our finding that leptin did not overcome the glucoprivic inhibition of LH secretion is that glucose and leptin share the same energetic pathway in the regulation of $\mathrm{LH}$ release. The mechanisms whereby leptin stimulates 
energy consumption are considered to involve increases in intracellular lipid $(17,18)$ and glucose metabolism (47-49). Regarding the latter possibility, leptin has been found to stimulate cellular glucose availability in the peripheral tissues by sensitizing insulin receptors $(50)$, glucose uptake $(47,48)$ and intracellular metabolism of glucose (47). It is plausible that exogenous leptin did not restore normal glucose metabolism, regardless of all of these positive actions to increase glucose availability, because $2 \mathrm{DG}$, by acting as a competitive antagonist at the hexokinase level (51), produced a shortage of oxidizable substrate. Such a hypothesis has been proposed recently by Schneider et al. (52) who found that glucoprivation (2DG) prevented the positive effect of leptin treatment on restoring oestrous cycles in fasting Syrian hamsters. It is also noteworthy that the infertile $o b / o b$ mouse which is leptin deficient has reduced glucose availability because of its type II diabetes (53). Taken together, the present results raise the possibility that leptin controls pulsatile GnRH release by modulating cellular glucose availability.

\section{Acknowledgements}

We thank Amgen Inc. for generously providing the leptin for experimental study; Ms J. Pelt for her technical assistance; the Assay and Reagents Core; and the Laboratory Assay Core (Core Facilities of the Center for the Study of Reproduction). A preliminary report of this work was presented at the The Endocrine Society 81st Annual Meeting, San Diego, CA, Abstract P2-21. This work was supported by research grants from the NIH (HD-18394 and 18258).

\section{Accepted 9 November 2000}

\section{References}

1 Bronson FH. Environmental regulation: some general principles. In Bronson FH, eds. Mammalian Reproductive Biology. Chicago: The University of Chicago Press, 1989: 7-27.

2 Cameron JL, Helmreich DL, Schreihofer DA. Modulation of reproductive hormone secretion by nutritional intake: stress signals versus metabolic signals. Hum Reprod 1993; 8 (Suppl.): 162-167.

3 Wade GN, Schneider JE, Li H-Y. Control of fertility by metabolic cues. Am J Physiol 1996; 270: E1-E19.

4 Foster DL, Nagatani S, Bucholtz DC, Tsukamura H, Tanaka T, Maeda K-I. Links between nutrition and reproduction: signals, sensors and pathways controlling GnRH secretion. In: Hansel W, McCann S, eds. Nutrition and Reproduction. Baton Rouge: LSU Press, 1998: 59-80.

5 Zhang Y, Proenca R, Maffei M, Barone M, Leopold L, Friedman JM Positional cloning of the mouse obese gene and its human homologue. Nature 1994; 372: 425-432.

6 Foster DL, Nagatani S. Physiological perspectives of leptin as a regulator of reproduction: role in timing puberty. Biol Reprod 1999; 60: $205-215$.

7 Cunningham MJ, Clifton DK, Steiner RA. Leptin's actions on the reproductive axis. Perspectives and mechanisms. Biol Reprod 1999; 60: $216-222$.

8 Nagatani S, Guthikonda P, Thompson RC, Tsukamura H, Maeda K-I, Foster DL. Evidence for GnRH regulation by leptin: leptin administration prevents reduced pulsatile LH secretion during fasting. Neuroendocrinology 1998; 67: 370-376.

9 Finn PD, Cunningham MJ, Pau K-YF, Spies HG, Clifton DK, Steiner RA. The stimulatory effect of leptin on the neuroendocrine reproductive axis of the monkey. Endocrinology 1998; 139: 4652-4662.

10 Nagatani S, Zeng Y, Keisler DH, Foster DL, Jaffe CA. Leptin regulates pulsatile luteinizing hormone and growth hormone secretion in the sheep. Endocrinology 2000; 141: 3965-3975.
11 Ahima RS, Prabakaran D, Mantzoros C, Qu D, Lowell B, MaratosFlier E, Flier JS. Role of leptin in the neuroendocrine response to fasting. Nature 1996; 382: 250-252.

12 Harris RBS, Zhou J, Redmann SM Jr, Smagin GN, Smith SR, Rodgers E, Zachwieja JJ. A leptin dose-response study in obese (ob/ob) and lean $(+/$ ? ) mice. Endocrinology 1998; 139: 8-19.

13 Maeda K-I, Cagampang FRA, Coen CW, Tsukamura H. Involvement of the catecholaminergic input to the paraventricular nucleus and of corticotropin-releasing hormone in the fasting-induced suppression of luteinizing hormone release in female rats. Endocrinology 1994; 134: 1718-1722.

14 Barash IA, Cheung CC, Weigle DS, Ren H, Kabigting EB, Kuijper JL, Clifton DK, Steiner RA. Leptin is a metabolic signal to the reproductive system. Endocrinology 1996; 137: 3144-3147.

15 Chehab FF, Lim ME, Ronghue L. Correction of the sterility defect in homozygous obese female mice by treatment with the human recombinant leptin. Nature Genet 1996; 12: 318-320.

16 Mounzih K, Lu R, Chehab FF. Leptin treatment rescues the sterility of genetically obese ob/ob males. Endocrinology 1997; 138: 1190-1193.

17 Shimabukuro M, Koyama K, Chen G, Wang MY, Trieu F, Lee Y, Newgard CB, Unger RH. Direct antidiabetic effect of leptin through triglyceride depletion of tissues. Proc Natl Acad Sci USA 1997; 94: 4637-4641.

18 Hwa JJ, Fawzi AB, Graziano MP, Ghibaudi L, Williams P, Van Heek M, Davis H, Rudinski M, Sybertz E, Strader CD. Leptin increases energy expenditure and selectively promotes fat metabolism in ob/ob mice. Am J Physiol 1997; 272: R1204-R1209.

19 Weidenfeld J, Corcos AP, Wohlman A, Feldman S. Characterization of the 2-deoxyglucose effect on the adrenocortical axis. Endocrinology 1994; 134: $1924-1931$.

20 Nagatani S, Bucholtz DC, Murahashi K, Estacio MAC, Tsukamura H, Foster DL, Maeda K-I. Reduction of glucose availability suppresses pulsatile LH release in female and male rats. Endocrinology 1996; 137: 1166-1170.

21 Heiman ML, Ahima RS, Craft LS, Schoner B, Stephens TW, Flier JS. Leptin inhibition of the hypothalamic-pituitary-adrenal axis in response to stress. Endocrinology 1997; 138: 3859-3863.

22 Nagatani S, Tsukamura H, Murahashi K, Bucholtz DC, Foster DL, Maeda K-I. Paraventricular norepinephrine release mediates glucoprivic suppression of pulsatile LH secretion. Endocrinology 1996; 137: 3183-3186.

23 Licinio J, Mantzoros C, Negrao AB, Cizza G, Wong ML, Bongiorno PB, Chrousos GP, Karp B, Allen C, Flier JS, Gold PW. Human leptin levels are pulsatile and inversely related to pituitary-adrenal function. Nat Med 1997; 3: 575-579.

24 Laughlin GA, Yen SS. Hypoleptinemia in women athletes: absence of a diurnal rhythm with amenorrhea. J Clin Endocrinol Metab 1997; 82: $318-321$.

25 Ahima RS, Prabakaran D, Flier JS. Postnatal leptin surge and regulation of circadian rhythm of leptin by feeding: implications for energy homeostasis and neuroendocrine function. J Clin Invest 1998; 101: $1020-1027$.

26 Murahashi K, Bucholtz DC, Nagatani S, Tsukahara S, Tsukamura H, Foster DL, Maeda K-I. Suppression of LH pulses by restriction of glucose availability is mediated by sensors in the brain stem. Endocrinology 1996; 137: 1171-1176.

27 Veldhuis JD, Johnson ML. Cluster analysis: a simple, versatile, and robust algorithm for endocrine pulse detection. Am J Physiol 1986; 250: E486-E493.

28 Bucholtz DC, Vidwans NM, Herbosa CG, Schillo KK, Foster DL. Metabolic interfaces between growth and reproduction. V. Pulsatile LH secretion is dependent upon glucose availability. Endocrinology 1996; 137: $601-607$.

29 Atkinson HC, Waddell BJ. Circadian variation in basal plasma corticosterone and adrenocorticotropin in the rat: sexual dimorphism and changes across the estrous cycle. Endocrinology 1997; 138: $3842-3848$.

30 Saladin R, De-Vos P, Guerre-Millo M, Leturque A, Girard J, Staels B, Auwerx J. Transient increase in obese gene expression after food intake or insulin administration. Nature 1995; 377: 527-529.

31 Mueller WM, Gregoire FM, Stanhope KL, Mobbs CV, Mizuno TM, Warden $\mathrm{CH}$, Stern JS, Havel PJ. Evidence that glucose metabolism 
regulates leptin secretion from cultured rat adipocytes. Endocrinology 1998; 139: 551-558.

32 Widmaier EP, Plotsky PM, Sutton SW, Vale WW. Regulation of corticotropin-releasing factor secretion in vitro by glucose. Am J Physiol 1988; 255: E287-E292.

33 Rivier C, Rivest S. Effect of stress on the activity of the hypothalamicpituitary-gonadal axis: peripheral and central mechanisms. Biol Reprod 1991; 45: 523-532.

34 Petraglia F, Sutton S, Vale W, Plotsky P. Corticotropin-releasing factor decreases plasma luteinizing hormone levels in female rats by inhibiting gonadotropin-releasing hormone release into hypophysial-portal circulation. Endocrinology 1987; 120: 1083-1088.

35 Rivier C, Vale W. Influence of corticotropin-releasing factor on reproductive function in the rat. Endocrinology 1984; 114: 914-921.

36 Almeida OF, Nikolarakis KE, Herz A. Evidence for the involvement of endogenous opioids in the inhibition of luteinizing hormone by corticotropin-releasing factor. Endocrinology 1988; 122: 1034-1041.

37 Olster DH, Ferin M. Corticotropin-releasing hormone inhibits gonadotropin secretion in the ovariectomized rhesus monkey. $J$ Clin Endocrinol Metab 1987; 65: 262-267.

38 Xiao E, Luckhaus J, Niemann W, Ferin M. Acute inhibition of gonadotropin secretion by corticotropin-releasing hormone in the primate: are the adrenal glands involved? Endocrinology 1989; 124: $1632-1637$.

39 Williams CL, Nishihara M, Thalabard JC, Grosser PM, Hotchkiss J, Knobil E. Corticotropin-releasing factor and gonadotropin-releasing hormone pulse generator activity in the rhesus monkey. Neuroendocrinology 1990; 52: 133-137.

40 Rivier C, Rivier J, Vale W. Stress-induced inhibition of reproductive functions: role of endogenous corticotropin-releasing factor. Science 1986; 231: 607-609.

41 Pralong FP, Roduit R, Waeber G, Castillo E, Mosimann F, Thorens B, Gaillard RC. Leptin inhibits directly glucocorticoid secretion by normal human and rat adrenal gland. Endocrinology 1998; 139: 42644268.
42 Hakansson ML, Brown H, Ghilardi N, Skoda RC, Meister B. Leptin receptor immunoreactivity in chemically defined target neurons of the hypothalamus. J Neurosci 1998; 18: 559-572.

43 Lechan RM, Nestler JL. The hypothalamic tuberoinfundibular system of the rat as demonstrated by horseradish peroxidase (HRP) microiontophoresis. Brain Res 1980; 195: 13-27.

44 Weigand SJ, Price JL. The cells of the afferent fibers to the median eminence in the rat. J Comp Neurol 1980; 192: 1-19.

45 MacLusky NJ, Naftolin F, Leranth C. Immunocytochemical evidence for direct synaptic connections between corticotropin-releasing factor (CRF) and gonadotropin-releasing hormone $(\mathrm{GnRH})$-containing neurons in the preoptic area of the rat. Brain Res 1988; 439: 391-395.

46 Rivest S, Plotsky PM, Rivier C. CRF alters the infundibular LHRH secretory system from the medial preoptic area of female rats: possible involvement of opioid receptors. Neuroendocrinology 1993; 57: 236-246.

47 Kamohara S, Burcelin R, Halaas JL, Friedman JM, Charron MJ. Acute stimulation of glucose metabolism in mice by leptin treatment. Nature 1997; 389: 374-377.

48 Minokoshi Y, Haque MS, Shimazu T. Microinjection of leptin into the ventromedial hypothalamus increases glucose uptake in peripheral tissues in rats. Diabetes 1999; 48: 287-291.

49 Friedman JM, Halaas JL. Leptin and the regulation of body weight in mammals. Nature 1998; 395: 763-770.

50 Sivitz WI, Walsh SA, Morgan DA, Thomas MJ, Haynes WG. Effects of leptin on insulin sensitivity in normal rats. Endocrinology 1997; 138: $3395-3401$.

51 Shepherd GM. Neurotransmitters and neuromodulators: Neurobiology. New York: Oxford, 1988: 145-174.

52 Schneider JE, Goldman MD, Tang S, Bean B, Ji H, Friedman MI. Leptin indirectly affects estrous cycles by increasing metabolic fuel oxidation. Horm Behav 1998; 33: 217-228.

53 Coleman DL. Obese and diabetes: two mutant genes causing diabetes-obesity syndromes in mice. Diabetologia 1978; 14: 141-148. 